\title{
Production of Extracellular Polymeric Substances by Halophilic Bacteria of Solar Salterns
}

\author{
Jhuma Biswas and A. K. Paul \\ Microbiology Laboratory, Department of Botany, University of Calcutta, 35 Ballygunge Circular Road, Kolkata 700 019, India \\ Correspondence should be addressed to A. K. Paul; amalk_paul@yahoo.co.in
}

Received 13 May 2014; Accepted 15 July 2014; Published 6 August 2014

Academic Editor: Yinguang Chen

Copyright (C) 2014 J. Biswas and A. K. Paul. This is an open access article distributed under the Creative Commons Attribution License, which permits unrestricted use, distribution, and reproduction in any medium, provided the original work is properly cited.

\begin{abstract}
Moderately halophilic aerobic bacteria were isolated from 31 soil and 18 water samples collected from multipond solar salterns of Gujarat, Orissa, and West Bengal, India. A total of 587 bacterial isolates with distinct morphological features were obtained from these samples following dilution and plating on $\mathrm{MH}$ agar medium supplemented with $\mathrm{NaCl}$. The isolates were screened for growth associated extracellular polymeric substances (EPS) production in MY medium under batch culture. In all, 20 isolates were selected as potent ones producing more than $1 \mathrm{~g} / \mathrm{L}$ of EPS. These EPS producing isolates were characterized in detail for their morphological, physiological, and biochemical features and tentatively identified as members belonging to the genera Halomonas, Salinicoccus, Bacillus, Aidingimonas, Alteromonas, and Chromohalobacter. Apart from EPS production, these isolates also hold promise towards the production of various biomolecules of industrial importance.
\end{abstract}

\section{Introduction}

Multipond solar salterns used for industrial production of marine salts by evaporation of sea water represent hypersaline environments which are popular habitats for studying halophilic bacteria and have great potential towards industrial and biotechnological applications $[1,2]$. The diversity of halophilic bacteria so far isolated and characterized is categorized into four different classes according to $\mathrm{NaCl}$ requirement for their growth and includes slight halophiles, moderate halophiles, extreme halophiles, and border line halophiles. The halotolerant bacteria on the other hand do not require $\mathrm{NaCl}$ for their growth but can tolerate a high salinity [3-5]. Halophilic diversity of solar salterns has been studied quite extensively across the globe and reviewed by several authors [6-8]. However, only very few studies have been made on the halophilic bacterial community in coastal solar salterns of India $[9,10]$, which deserves special attention for exploration and commercial exploitation of these microbial resources.

Extracellular polymeric substances (EPS) are one of the industrially important compounds produced by a wide variety of marine microorganisms. Due to growing biotechnological interest [11], production of bacterial EPS has become an attractive field of research. EPS is used as thickeners, emulsifiers, and suspending agents in food, pharmaceuticals, and petroleum industries. They are also used as adhesives in detergents, textiles, papers, paints, and beverages industries. Moreover, EPS are used as metal removers and bioabsorbers in oil recovery, mining, and petroleum industries [12].

During the course of extensive search for new strains producing extracellular polymeric substances (EPS) in their natural hypersaline environments, large numbers of halophilic bacteria and archaea have been established as EPS producers. Most of them belong to the genera Haloferax, Haloarcula, Halococcus, Natronococcus, and Halobacterium $[13,14]$. Nevertheless, the common halophilic EPS producing bacteria belong to the genus Halomonas, most importantly $H$. maura [8], $H$. eurihalina [15], $H$. ventosae, and $H$. anticariensis [16]. Exopolysaccharides synthesized by Halomonas strains unusually have high sulphate content and a significant amount of uronic acids determining their good gelifying properties. Moreover, recent reports have 
also established that halophilic EPS producers belong to the gamma-proteobacteria (Idiomarina and Alteromonas) as well as alpha-proteobacteria (Salipiger mucosus and Palleronia marisminoris) $[17,18]$.

This study is focused on the isolation of halophilic bacteria from water and soil samples of some selected solar salterns located in the states of Gujarat, Orissa, and West Bengal, India, and evaluation of their EPS production efficiency under laboratory conditions. Attempts have also been made on the tentative identification of some potent EPS producing halophilic isolates based on their morphological and physiobiochemical features.

\section{Materials and Methods}

2.1. Collection of Samples. Soil and water samples from multipond solar salterns situated along the coast of Gujarat, Orissa, and West Bengal, India, were collected in sterile polypropylene containers and stored at $4^{\circ} \mathrm{C}$ until used for isolation of halophilic bacteria. A total of 12 soil and 7 water samples were collected from Jogrinar $\left(23^{\circ} 13^{\prime} \mathrm{N}\right.$ and $\left.69^{\circ} 59^{\prime} 51^{\prime \prime} \mathrm{E}\right)$, Khari Rohar $\left(23^{\circ} 4^{\prime} 16^{\prime \prime} \mathrm{N}\right.$ and $\left.70^{\circ} 9^{\prime} 37^{\prime \prime} \mathrm{E}\right)$, Kandla $\left(22^{\circ} 59^{\prime} \mathrm{N}\right.$ and $\left.70^{\circ} 13^{\prime} \mathrm{E}\right)$, and Albert Victor Port $\left(21^{\circ} 0^{\prime} 58^{\prime \prime} \mathrm{N}\right.$ and $\left.71^{\circ} 32^{\prime} 54^{\prime \prime} \mathrm{E}\right)$ of Gujarat. Similarly 10 soil and 5 water samples were collected from Surala $\left(19^{\circ} 84^{\prime} 73^{\prime \prime} \mathrm{N}\right.$ and $\left.84^{\circ} 65^{\prime} \mathrm{E}\right)$ and Humma $\left(19^{\circ} 26^{\prime} \mathrm{N}\right.$ and $\left.85^{\circ} 5^{\prime} \mathrm{E}\right)$, the two major solar salterns of Orissa. In West Bengal, the sampling sites were located at Dadanpatrabar $\left(22^{\circ} 26^{\prime} \mathrm{N}\right.$ and $\left.87^{\circ} 20^{\prime} \mathrm{E}\right)$ and Baksal $\left(22^{\circ} 1^{\prime} \mathrm{N}\right.$ and $\left.87^{\circ} 67^{\prime} \mathrm{E}\right)$ of East Midnapur, and a total of 9 soil and 6 water samples were collected.

2.2. Isolation of Halophilic Bacteria. Aerobic, heterotrophic, and halophilic bacteria of soil and water samples were isolated by serial dilution and plating on $\mathrm{MH}$ agar medium [19] supplemented with different concentrations of $\mathrm{NaCl}$. The medium contained $(\mathrm{g} / \mathrm{L})$ yeast extract, 10; protease peptone, 5; glucose, 1; $\mathrm{NaCl}, 100 ; \mathrm{MgCl}_{2} 6 \mathrm{H}_{2} \mathrm{O}, 7 ; \mathrm{MgSO}_{4} 7 \mathrm{H}_{2} \mathrm{O}$, 9.6; $\mathrm{CaCl}_{2} 2 \mathrm{H}_{2} \mathrm{O}, 0.36 ; \mathrm{KCl}, 2 ; \mathrm{NaHCO}_{3}, 0.06$; and $\mathrm{NaBr}, 0.026$ ( $\mathrm{pH}$ 7.2). The plates were incubated at $37^{\circ} \mathrm{C}$ for 3 to 5 days, and bacterial colonies with distinct morphology were isolated in pure form and maintained on slopes of the same medium. Total bacterial counts were expressed as colony forming units (cfu) $/ \mathrm{mL}$ and $/ \mathrm{g}$ of water and soil, respectively.

\subsection{Screening of Halophilic Bacteria for EPS Production.} To evaluate the EPS production capability, the bacterial isolates were grown in MY medium [20] supplemented with $5 \% \mathrm{NaCl}$ for 12 days at $32^{\circ} \mathrm{C}$ under continuous shaking $(120 \mathrm{rpm})$. The medium contained $(\mathrm{g} / \mathrm{L}) \mathrm{NaCl}, 50 ; \mathrm{MgCl}_{2}$ $6 \mathrm{H}_{2} \mathrm{O}, 9 ; \mathrm{MgSO}_{4} 7 \mathrm{H}_{2} \mathrm{O}, 13 ; \mathrm{CaCl}_{2} 2 \mathrm{H}_{2} \mathrm{O}, 0.2 ; \mathrm{KCl}, 1.3 ;$ $\mathrm{NaHCO}_{3}, 0.05 ; \mathrm{NaBr}, 0.15 ; \mathrm{FeCl}_{3} 6 \mathrm{H}_{2} \mathrm{O}, 0.005$; glucose, 10; yeast extract, 3; malt extract, 3 ; and protease peptone, 5 (pH 7.2). The EPS from the growing culture was isolated using the method as described by Quesada et al. [15]. The culture was centrifuged (at $10,000 \times \mathrm{g}$ for $10 \mathrm{~min}$ ), the EPS in the supernatant was precipitated with chilled ethanol, and recovered by centrifugation $(12000 \times \mathrm{g}$ for $10 \mathrm{~min})$ and washed with chilled $70 \%$ ethanol. The washed precipitate was collected by centrifugation, dissolved in known volume of distilled water, and used for quantification and chemical analysis.

2.4. Chemical Analysis of EPS. Total carbohydrate content of the EPS was estimated following the method of Dubois et al. [21]. To $1 \mathrm{~mL}$ of dissolved EPS sample, $0.5 \mathrm{~mL}$ of $5 \%$ phenol and $3.5 \mathrm{~mL}$ of concentrated sulfuric acid were added and incubated at $30-40^{\circ} \mathrm{C}$ for $10-20$ minutes in hot water bath. Absorbance was read at $490 \mathrm{~nm}$, and the amount of carbohydrate was determined from the calibration curve prepared using glucose as standard.

Protein content of the EPS was determined following the Folin phenol method of Lowry et al. [22]. To $1 \mathrm{~mL}$ of EPS sample, $5 \mathrm{~mL}$ of alkaline solution and $0.5 \mathrm{~mL}$ of Folin phenol reagent were added and incubated for 30 minutes at room temperature in dark. The absorbance was measured at $670 \mathrm{~nm}$, and the concentration was read from the calibration curve prepared by using bovine serum albumin (BSA) as the standard.

\subsection{Characterization and Identification of Selected Bacterial} Isolates. The selected bacterial isolates were characterized morphologically and physiobiochemically following standard microbiological methods as described by Gerhardt et al. [23]. To determine the antibiotic sensitivity pattern of these isolates, the antibiotic impregnated discs (Himedia, $6 \mathrm{~mm}$ dia.) were placed on $\mathrm{MH}$ agar plates seeded with respective bacterial isolates. The plates were incubated for $24 \mathrm{~h}$ at $32^{\circ} \mathrm{C}$, and diameter of inhibition zones was measured to the nearest $\mathrm{mm}$. Production of acids from sugars by the bacterial isolates was tested on phenol red medium supplemented with $1 \%$ carbon source. Characteristics of the bacterial isolates were compared with those described in Bergey's Manual of Systematic Bacteriology [24] and that of Mata et al. [25] for determination of taxonomic identity.

\section{Results}

3.1. Isolation of Halophilic Bacteria. A total of 31 soil and 18 water samples collected from 8 different sites spread over the states of Gujarat, Orissa, and West Bengal, India, were analyzed for the aerobic, heterotrophic, and halophilic bacteria following dilution and plating on $\mathrm{MH}$ agar medium supplemented with 5,10 , and $15 \% \mathrm{NaCl}$. The total bacterial population of both soil and water samples as determined by colony forming units varied considerably and declined gradually irrespective of sampling sites with increasing $\mathrm{NaCl}$ concentration in the isolation medium (Tables 1 and 2).

A total of 587 halophilic and halotolerant, heterotrophic, and aerobic bacterial isolates were obtained in pure form. The majority of these isolates (410) were derived from soil samples (Table 3), while 177 were obtained from water samples (Table 4). Most of the isolates were Gram-negative, motile, aerobic 
TABLE 1: Bacterial population of soil samples collected from solar salterns of Gujarat, Orissa, and West Bengal, India.

\begin{tabular}{|c|c|c|c|c|c|}
\hline \multirow{3}{*}{ State } & \multirow{3}{*}{ Sampling sites } & \multirow{3}{*}{ Number of samples } & \multicolumn{3}{|c|}{ Bacterial count $\left(\mathrm{cfu} / \mathrm{g}\right.$ of soil $\left.\times 10^{2}\right)$} \\
\hline & & & \multicolumn{3}{|c|}{$\mathrm{NaCl}(\%)$ in medium } \\
\hline & & & 5 & 10 & 15 \\
\hline \multirow{4}{*}{ Gujarat } & Jogrinar & 4 & $0.74-86.6$ & $0.21-36.6$ & $0.11-4$ \\
\hline & Kandla Port & 3 & $0.86-7.35$ & $1.21-2.11$ & $0.08-0$ \\
\hline & Khari Rohar & 3 & $2.39-7.68$ & $0.12-17.8$ & $0.47-9.66$ \\
\hline & Victor Port & 2 & $1.73-2.83$ & $0.40-0$ & - \\
\hline \multirow{2}{*}{ Orissa } & Humma & 5 & $0.13-0.61$ & $0.25-0.55$ & - \\
\hline & Surala & 5 & $1-3.66$ & $0.07-0.23$ & - \\
\hline \multirow{2}{*}{ West Bengal } & Baksal & 4 & $2-3.90$ & $0.20-0.40$ & $0.20-0$ \\
\hline & Dadanpatrabar & 5 & $2.7-7.9$ & $0.07-0.60$ & $0.07-0.30$ \\
\hline
\end{tabular}

TABLE 2: Bacterial population of water samples collected from solar salterns of Gujarat, Orissa, and West Bengal, India.

\begin{tabular}{|c|c|c|c|c|c|}
\hline \multirow{3}{*}{ States } & \multirow{3}{*}{ Sampling sites } & \multirow{3}{*}{ Number of samples } & \multicolumn{3}{|c|}{ Bacterial count $\left(\mathrm{cfu} / \mathrm{mL}\right.$ of water $\left.\times 10^{2}\right)$} \\
\hline & & & \multicolumn{3}{|c|}{$\mathrm{NaCl}(\%)$ in medium } \\
\hline & & & 5 & 10 & 15 \\
\hline \multirow{4}{*}{ Gujarat } & Jogrinar & 2 & $0.28-5.56$ & $1.72-0$ & $0.40-0$ \\
\hline & Kandla Port & 2 & $0.53-5.40$ & $0.16-1.1$ & $0.66-0$ \\
\hline & Khari Rohar & 1 & $0.23-0$ & - & - \\
\hline & Victor Port & 2 & $12.6-190$ & - & - \\
\hline \multirow{2}{*}{ Orissa } & Humma & 3 & $0.23-2.3$ & - & - \\
\hline & Surala & 2 & $0.27-1.20$ & $0.83-0$ & - \\
\hline \multirow{2}{*}{ West Bengal } & Baksal & 3 & $1.10-1.36$ & $0.13-0.6$ & $0.10-0.37$ \\
\hline & Dadanpatrabar & 3 & $0.5-1.90$ & $0.07-0.50$ & $0.1-0.2$ \\
\hline
\end{tabular}

rods and produced white to cream colored, circular, smoothedged colonies on $\mathrm{MH}$ agar. In general, the isolates were capable of tolerating wide range of temperature and $\mathrm{pH}$ for their growth.

3.2. Screening for EPS Production. EPS producing ability of these isolates was examined in batch culture using MY medium supplemented with $5 \% \mathrm{NaCl}$, and the soluble EPS content of each of the isolates was evaluated in terms of its carbohydrate content as determined by Dubois method [21]. Among the 410 soil isolates, majority (184) produced soluble EPS ranging from 0.5 to $0.7 \mathrm{~g} / \mathrm{L}$ in terms of their carbohydrate content, while only 15 isolates produced more than $1 \mathrm{~g} / \mathrm{L}$ of EPS (Table 5). On the contrary, among the 177 bacterial strains isolated from saline water samples, only 5 produced soluble EPS accounting for more than $1 \mathrm{~g} / \mathrm{L}$ of carbohydrate. However, majority (77) of them produced $0.5-$ $0.7 \mathrm{~g} / \mathrm{L}$ of soluble EPS (Table 6).

In all, 20 potent isolates producing $>1 \mathrm{~g} / \mathrm{L}$ of EPS were further allowed to grow in MY medium under continuous shaking $(120 \mathrm{rpm})$, and the soluble EPS produced after 8 days of growth was estimated following the method as described above. Kinetics of growth and EPS production revealed that EPS production by these isolates increased with biomass formation (Figure 1), and a few of the selected isolates such as SUR202, SUR307, SUR310, JW307, and
JS904 appeared to be promising with an EPS yield of $1.68-1.85 \mathrm{~g} / \mathrm{L}$.

3.3. Characterization and Identification of Selected Bacterial Isolates. Morphological and physiological studies revealed (Table 7) that these halophilic bacteria (with the exception of isolate SUR303) formed cream colored smooth colonies on $\mathrm{MH}$ agar medium. Most of them were Gram-negative, motile rods; only three isolates were Gram-positive; one of them (isolate SUS303) was coccus, while the isolate KW203 was the only endospore former. The isolates were capable of tolerating $15-20 \% \mathrm{NaCl}$ in the medium and a $\mathrm{pH}$ of $5-$ 11. Optimum growth was observed at a temperature of 32$37^{\circ} \mathrm{C}$, but all were able to tolerate a temperature as high as $40^{\circ} \mathrm{C}$.

Analysis of biochemical characters (Table 8) showed that the majority of these halophilic isolates gave negative response to MR-VP tests and failed to produce extracellular enzymes like amylase, cellulase, pectinase, inulinase, gelatinase, lipase, caseinase, xylanase, and urease. None of these isolates, however, were capable of producing $\mathrm{H}_{2} \mathrm{~S}$, lysine-, arginine-, and ornithine decarboxylase.

Carbon source utilization pattern (Table 9) of these halophilic isolates varied considerably. All the isolates were able to utilize ribose, fructose, mannitol, salicin, cellobiose, acetate, benzoate, and succinate, and three of them (JS803, 
TABLE 3: Bacterial isolates obtained from soil samples of solar salterns of Gujarat, Orissa, and West Bengal, India.

\begin{tabular}{|c|c|c|c|c|c|}
\hline \multirow{3}{*}{ States } & \multirow{3}{*}{ Sampling sites } & \multirow{3}{*}{ Number of samples } & \multicolumn{3}{|c|}{ Number of bacterial isolates } \\
\hline & & & \multicolumn{3}{|c|}{$\mathrm{NaCl}(\%)$ in medium } \\
\hline & & & 5 & 10 & 15 \\
\hline \multirow{4}{*}{ Gujarat } & Jogrinar & 4 & 44 & 23 & 4 \\
\hline & Kandla Port & 3 & 19 & 12 & 4 \\
\hline & Khari Rohar & 3 & 46 & 16 & 6 \\
\hline & Victor Port & 2 & 20 & 5 & - \\
\hline \multirow{2}{*}{ Orissa } & Humma & 5 & 48 & 14 & - \\
\hline & Surala & 5 & 31 & 31 & 2 \\
\hline \multirow{2}{*}{ West Bengal } & Baksal & 4 & 19 & 8 & 3 \\
\hline & Dadanpatrabar & 5 & 29 & 16 & 10 \\
\hline Total & & 31 & 256 & 125 & 29 \\
\hline
\end{tabular}

TABLE 4: Bacterial isolates obtained from water samples of solar salterns of Gujarat, Orissa, and West Bengal, India.

\begin{tabular}{|c|c|c|c|c|c|}
\hline \multirow{3}{*}{ States } & \multirow{3}{*}{ Sampling sites } & \multirow{3}{*}{ Number of samples } & \multirow{2}{*}{\multicolumn{3}{|c|}{$\begin{array}{l}\text { Number of bacterial isolates } \\
\mathrm{NaCl}(\%) \text { in medium }\end{array}$}} \\
\hline & & & & & \\
\hline & & & 5 & 10 & 15 \\
\hline \multirow{4}{*}{ Gujarat } & Jogrinar & 2 & 21 & 14 & 5 \\
\hline & Kandla Port & 2 & 19 & 5 & 2 \\
\hline & Khari Rohar & 1 & 1 & 3 & - \\
\hline & Victor Port & 2 & 26 & 一 & 1 \\
\hline \multirow{2}{*}{ Orissa } & Humma & 3 & 16 & - & - \\
\hline & Surala & 2 & 12 & 8 & 3 \\
\hline \multirow{2}{*}{ West Bengal } & Baksal & 3 & 9 & 3 & 4 \\
\hline & Dadanpatrabar & 3 & 17 & 4 & 4 \\
\hline Total & & 18 & 121 & 37 & 19 \\
\hline
\end{tabular}

SUR301, and SUR307) appeared to be versatile in utilizing all 30 carbon sources. Fermentation pattern of these strains varied remarkably; the majority were unable to ferment most of the carbon sources. On the contrary, fructose, sorbitol, and benzoate were fermented by most of the isolates (Table 9).

Sensitivity of these isolates to 22 different antibiotics was tested by disc-diffusion method (Table 10), and the antibiotic resistance index (ARI) was determined (Figure 2). The majority of the isolates were sensitive to chloramphenicol $(30 \mu \mathrm{g})$, gentamycin $(10 \mu \mathrm{g})$, and norfloxacin $(10 \mu \mathrm{g})$ followed by ampicillin $(10 \mu \mathrm{g})$. Resistance to vancomycin $(30 \mu \mathrm{g})$ followed by trimethoprim $(30 \mu \mathrm{g})$ was predominant amongst the tested halophiles. As judged by the ARI values, the isolate SUR302 was the most resistant one $(A R I=0.65)$ followed by SUR301, KW203, and KW1805, while the lowest ARI (0.23) was indicated by the isolate JW307, which was most sensitive to the tested antibiotics.

The morphological, physiological, and biochemical characters including the carbon source utilization and fermentation patterns along with antibiotic susceptibility were analyzed and compared with the phenotypic characters of halophilic bacterial genera $[5,18]$ so far reported. According to the phenotypic and biochemical characteristics, $70 \%$ of the selected isolates (14) were tentatively identified as members of the genus Halomonas. The only Gram-positive coccus (isolate SUR303) and the rod shaped endospore forming isolate (isolate KW203) were assigned to Salinicoccus and Bacillus, respectively. Two of the isolates (KS1805 and SUR301) were placed in the genus Chromohalobacter, while the remaining two (isolates JS504 and JS904) were included under Alteromonas and Aidingimonas, respectively.

\section{Discussion}

Halophiles have mainly been isolated from wide diversity of environments such as saltern crystallizer ponds, the Dead Sea, solar lakes, and hypersaline lakes [26]. Culture dependent diversity studies on halophiles have been made from Tunisian solar saltern [27, 28], Tuzkoy salt mine [29], Sereflikochisar Salt Lake [30], Kaldirim and Kayacik of Tuz Lake [31], Turkey, Howz Soltan Lake, Iran [32], and hypersaline environments in South Spain [33-36]. In the Indian context, the halophilic diversity studies have been restricted mainly to the marine salterns of Bhavnagar [37-40], Lonar Lake [40], and Peninsular Coast $[41,42]$. The present study reports 
TABLE 5: Screening of halophilic bacterial isolates derived from soil samples for the production of extracellular polymeric substances.

\begin{tabular}{|c|c|c|c|c|c|c|}
\hline \multirow{2}{*}{ States } & \multirow{2}{*}{ Sampling sites } & \multirow{2}{*}{ Number of isolates } & \multicolumn{4}{|c|}{ Extracellular polymeric substances $(\mathrm{g} / \mathrm{L})$} \\
\hline & & & $>0.50$ & $0.51-0.70$ & $0.71-1.0$ & $>1.0$ \\
\hline \multirow{4}{*}{ Gujarat } & Jogrinar & 71 & 18 & 42 & 7 & 4 \\
\hline & Kandla Port & 35 & 13 & 13 & 7 & 2 \\
\hline & Khari Rohar & 68 & 26 & 31 & 11 & - \\
\hline & Victor Port & 25 & 20 & 3 & 2 & - \\
\hline \multirow{2}{*}{ Orissa } & Humma & 62 & 22 & 37 & 3 & - \\
\hline & Surala & 64 & 15 & 25 & 15 & 9 \\
\hline \multirow{2}{*}{ West Bengal } & Baksal & 30 & 14 & 12 & 4 & - \\
\hline & Dadanpatrabar & 55 & 32 & 21 & 2 & - \\
\hline Total & & 410 & 160 & 184 & 51 & 15 \\
\hline
\end{tabular}

TABLE 6: Screening of halophilic bacterial isolates derived from water samples for the production of extracellular polymeric substances.

\begin{tabular}{|c|c|c|c|c|c|c|}
\hline \multirow{2}{*}{ States } & \multirow{2}{*}{ Sampling sites } & \multirow{2}{*}{ Number of isolates } & \multicolumn{4}{|c|}{ Extracellular polymeric substances (g/L) } \\
\hline & & & $>0.50$ & $0.51-0.70$ & $0.71-1.0$ & $>1.0$ \\
\hline \multirow{4}{*}{ Gujarat } & Jogrinar & 40 & 26 & 9 & 3 & 2 \\
\hline & Kandla Port & 26 & 13 & 11 & 1 & 1 \\
\hline & Khari Rohar & 4 & 1 & 3 & - & - \\
\hline & Victor Port & 27 & 7 & 17 & 1 & 2 \\
\hline \multirow{2}{*}{ Orissa } & Humma & 16 & 4 & 11 & 1 & - \\
\hline & Surala & 23 & 8 & 6 & 9 & - \\
\hline \multirow{2}{*}{ West Bengal } & Baksal & 16 & 7 & 6 & 3 & - \\
\hline & Dadanpatrabar & 25 & 8 & 14 & 3 & - \\
\hline Total & & 177 & 74 & 77 & 21 & 5 \\
\hline
\end{tabular}

the distribution of halophilic and halotolerant bacterial communities in the inland multipond solar salterns spread over the coasts of India. Halophilic bacterial communities of 31 soil and 18 water samples from 8 different sites were analyzed by dilution and plating method (Tables 1 and 2 ) and provide information regarding the availability and diversity of halophilic bacteria in the solar saltern ponds. Colony forming units of soil and water samples revealed that soil samples hold more viable bacterial counts than water samples. Raghavan and Furtado [41] studied the occurrence of extremely halophilic archaea in sediments from the continental shelf of west coast of India and reported the presence of relatively low average counts $\left(7-5 \times 10^{3}\right)$ of extreme halophiles in offshore sediments in contrast to the very high counts $\left(10^{5}-10^{9}\right)$ of marine eubacteria. Similar study by Joshi et al. [40] reported that the total numbers of microorganisms in the soil and water samples were $10^{2}-10^{6} \mathrm{cfu} / \mathrm{g}$ and $10^{2}-10^{4} \mathrm{cfu} / \mathrm{mL}$, respectively.

A total of 587 halophilic and halotolerant bacterial strains were isolated showing different degrees of $\mathrm{NaCl}$ tolerance (Tables 3 and 4) and supported the observations of Quesada et al. [35] and Ventosa et al. [34]. However, during the present study we were unable to isolate extreme halophiles, which have frequently been identified as the dominant phylotypes in hypersaline environments along with solar salterns of India
[39, 41]. Furthermore, soil samples showed more bacterial diversity than water ones, which is in accordance with the observations of Joshi et al. [40].

During the course of screening of the moderately halophilic isolates for EPS production (Tables 5 and 6), only 20 isolates appeared to be promising with significant yield of EPS (1.0-1.85 g/L) (Figure 1). Joshi and coworkers [40] similarly screened 86 halophilic bacteria from Lonar Lake and reported Halomonas campisalis and Vagococcus carniphilus as potent EPS producers. Similarly, Nanjani and Soni [43] also isolated 73 halotolerant and halophilic bacteria from soil samples of Veraval and Dwarka; 23 of them produced EPS ranging from 0.2 to $10.60 \mathrm{~g} / \mathrm{L}$. In addition reports on EPS production by moderately halophilic bacteria of the genus Halomonas are not uncommon [8, 15-17].

Attempts have been made to determine the taxonomic identity of all 20 promising EPS producing isolates following detailed physiobiochemical characterization (Tables 7-9) and comparison with Bergey's Manual of Systematic Bacteriology [24] and those of Mata et al. [25]. The majority (14 isolates) of them were Gram-negative, nonsporulating rods and capable of growing in 2.5-20\% NaCl similar to those of Halomonas as reported by Quesada et al. [36], Ghozlan et al. [44], and Mata et al. [25]. However, the Gram-positive endospore forming isolate KW203 was assigned to the genus Bacillus. 


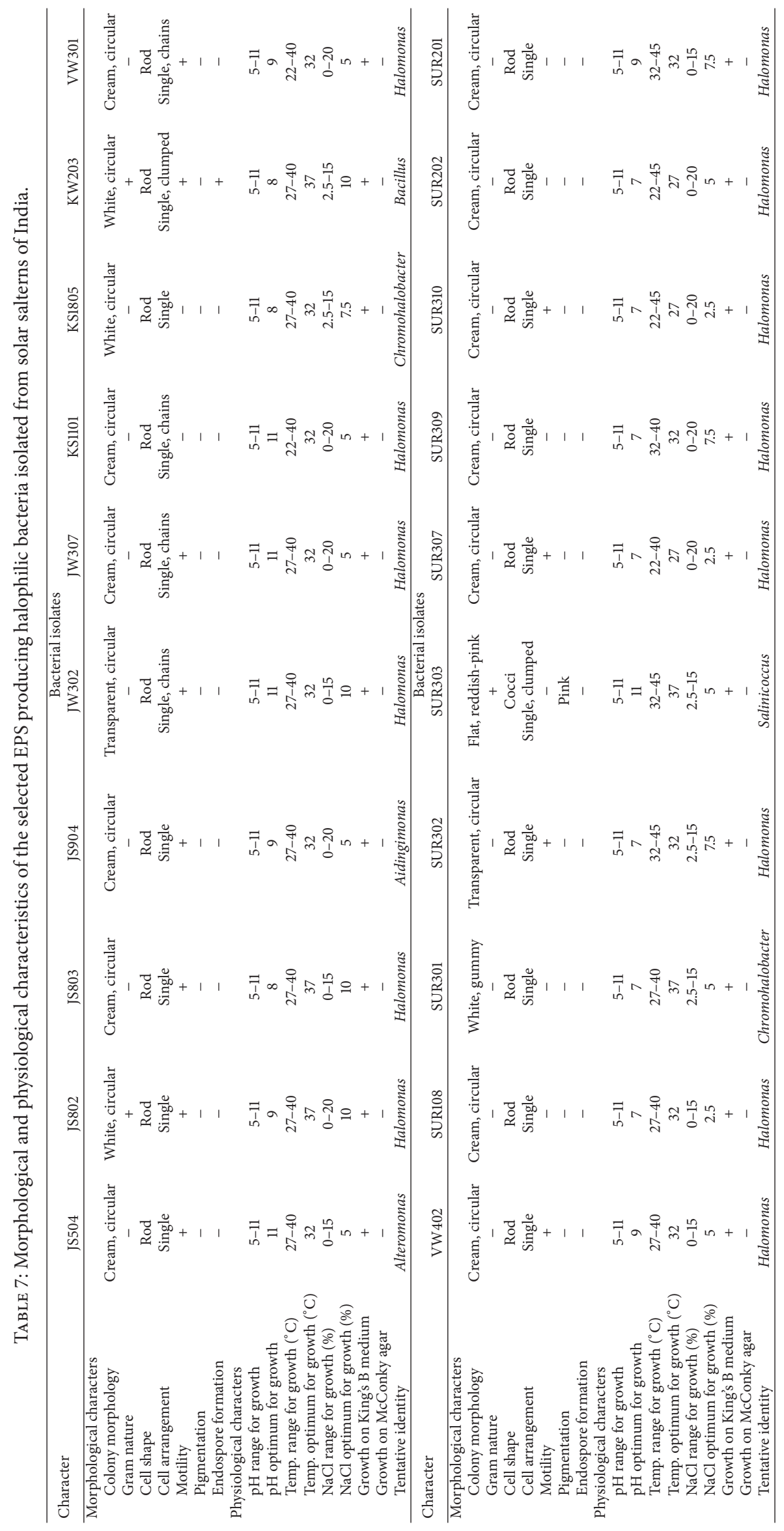




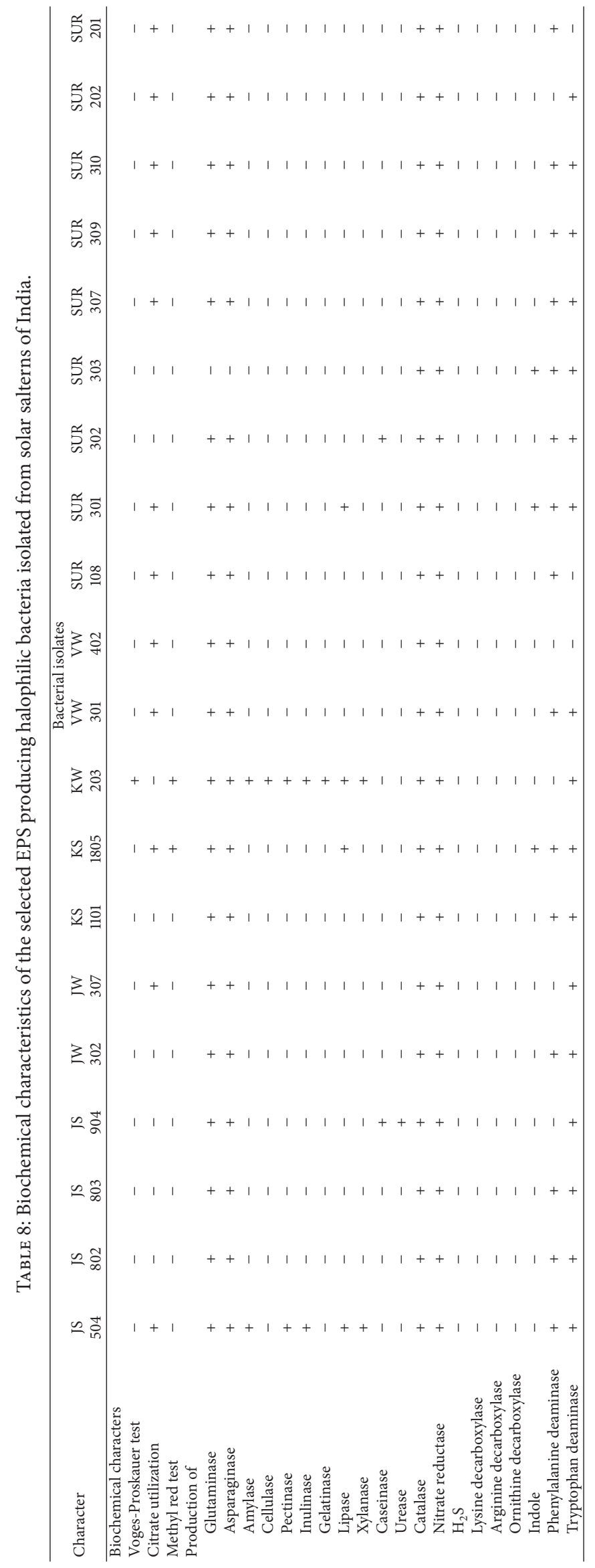




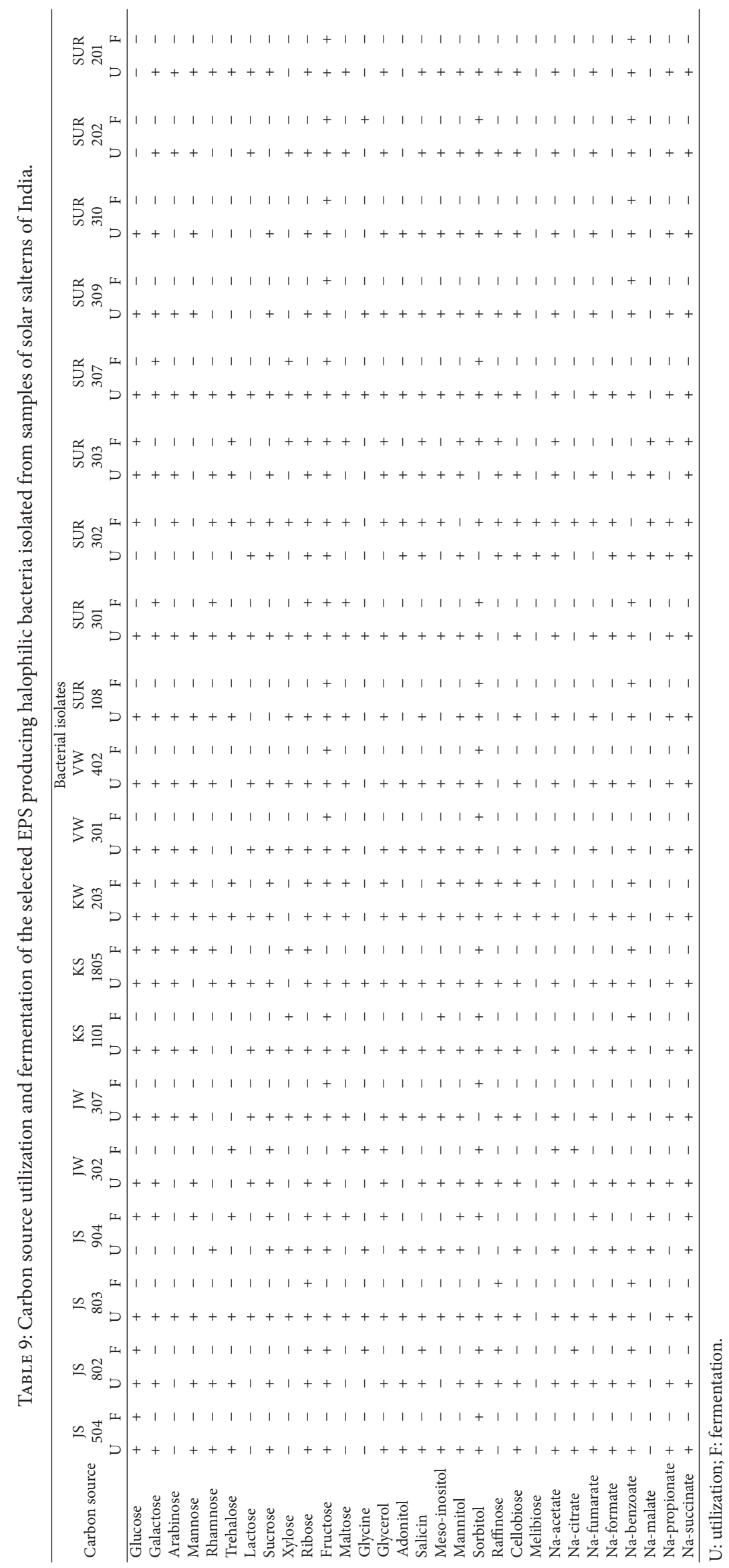




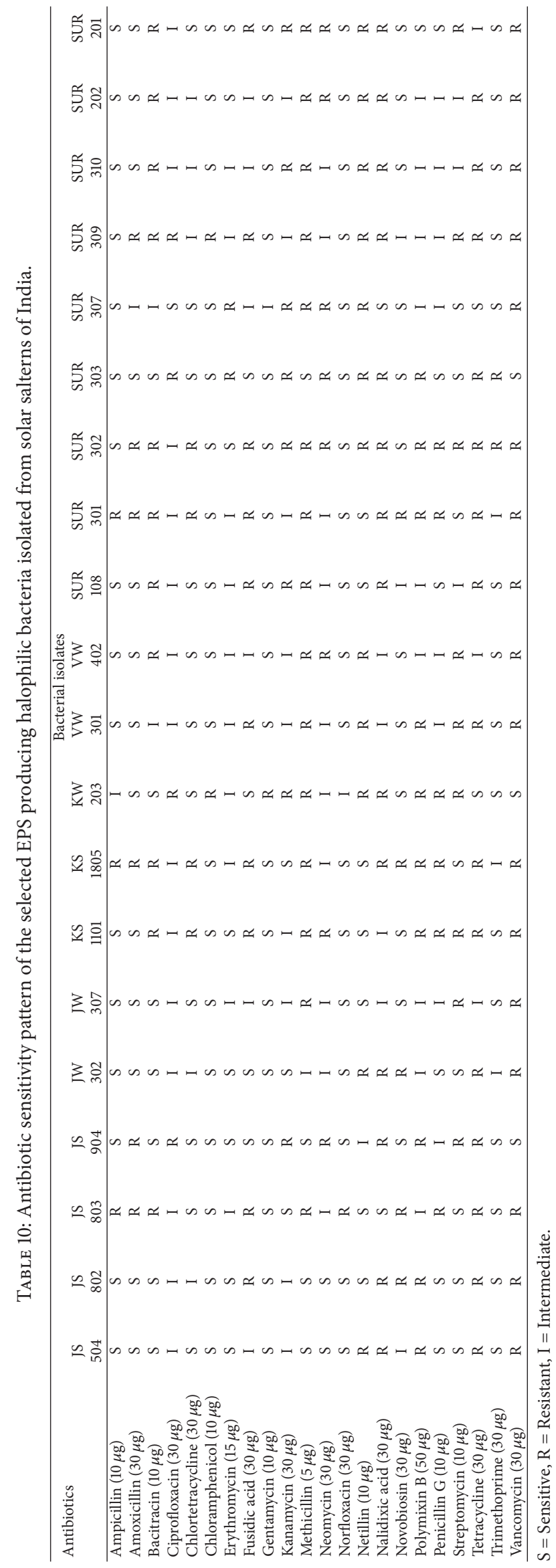




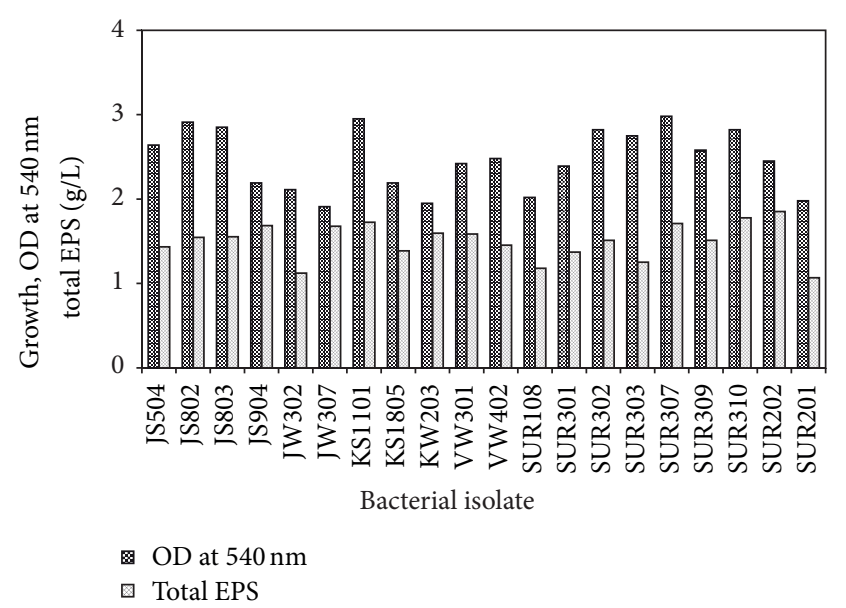

FIGURE 1: Screening of moderately halophilic bacteria isolated from soil and water samples of solar salterns for production of extracellular polymeric substances.

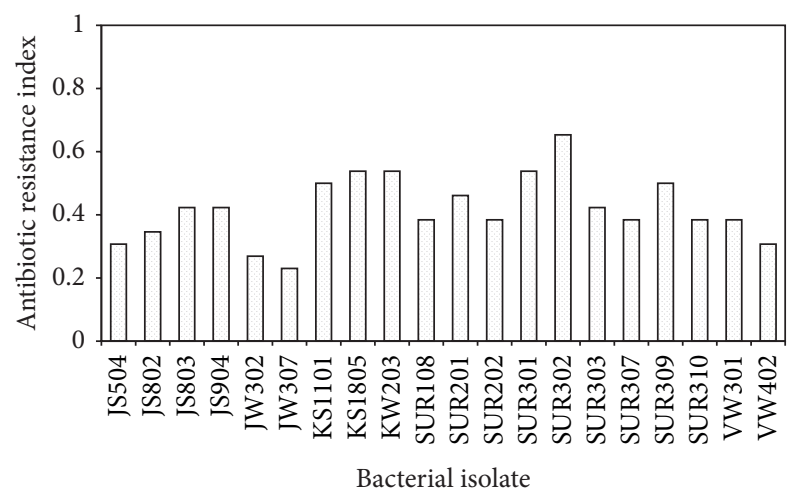

FIGURE 2: Antibiotic resistance index of the selected EPS producing halophilic bacteria isolated from soil and water samples of solar salterns of India.

The isolates SUR301 and KS 1805 were tentatively identified as Chromohalobacter based on the study by Arahal et al. [45] and bear striking similarity with those of Chromohalobacter sp. isolated from hypersaline soil sample of Triveni Sangam, Gujarat [38]. The physiological, morphological, and biochemical characteristics of isolate SUR303 were consistent with the features of the genus Salinicoccus [10], while isolates JS904 and JS504 were tentatively assigned to Aidingimonas and Alteromonas, respectively.

Finally, sensitivity of these isolates to antibiotics (Table 10 and Figure 2) also corroborates the findings of Mata et al. [25] and Hedi et al. [28].

\section{Conclusion}

It may be emphasized that study of these moderately halophilic bacteria from coastal hypersaline solar salterns of India with special attempt on screening for EPS production has led to the discovery of wide variety of halophilic species. Although attention has been focused on the production of EPS by these halophilic bacterial isolates, their physiobiochemical features indicate that they may equally hold potential towards production of various biomolecules of industrial interest.

\section{Conflict of Interests}

It is declared by the authors that there is no conflict of interests regarding the publication of this paper.

\section{Acknowledgment}

This study was financially supported by grants from University Grants Commission, India, (Sanction no. F.142(SC)/2008 (SA-III), 31 March, 2009) under the Scheme of Rajiv Gandhi National Fellowship.

\section{References}

[1] E. A. Galinski and B. J. Tindall, "Biotechnological prospects for halophiles and halotolerant microorganisms," in Molecular Biology and Biotechnology of Extremophiles, R. D. Herbert and R. J. Sharp, Eds., Blackie, London, UK, 1992.

[2] R. Margesin and F. Schinner, "Potential of halotolerant and halophilic microorganisms for biotechnology," Extremophiles, vol. 5, no. 2, pp. 73-83, 2001.

[3] F. Rodriguez Valera, F. Ruiz Berraquero, and A. Ramos Cormenzana, "Characteristics of the heterotrophic bacterial populations in hypersaline environments of different salt concentrations," Microbial Ecology, vol. 7, no. 3, pp. 235-243, 1981.

[4] F. Rodriguez-Valera, "Characteristics and microbial ecology of hypersaline environments," in Halophilic Bacteria, F. Rodriguez-Valera, Ed., vol. 1, pp. 3-30, CRC Press, Boca Raton, Fla, USA, 1988.

[5] D. J. Kushner and M. Kamekura, "Physiology of halophilic eubacteria," in Halophilic Bacteria, F. Rodriguez-Valera, Ed., vol. 1, pp. 109-138, CRC press, Boca Raton, Fla, USA, 1988.

[6] M. A. Amoozegar, F. Malekzadeh, and K. A. Malik, "Production of amylase by newly isolated moderate halophile, Halobacillus sp. strain MA-2," Journal of Microbiological Methods, vol. 52, no. 3, pp. 353-359, 2003.

[7] C. O. Jeon, J. Lim, J. Lee et al., "Lentibacillus salarius sp. nov., isolated from saline sediment in China, and emended description of the genus Lentibacillus," International Journal of Systematic and Evolutionary Microbiology, vol. 55, no. 3, pp. 1339-1343, 2005.

[8] S. Bouchotroch, E. Quesada, A. Del Moral, I. Llamas, and V. Béjar, "Halomonas maura sp. nov., a novel moderately halophilic, exopolysaccharide-producing bacterium," International Journal of Systematic and Evolutionary Microbiology, vol. 51, no. 5, pp. 1625-1632, 2001.

[9] A. Biswas, A. Patra, and A. Paul, "Production of poly-3hydroxyalkanoic acids by a moderately halophilic bacterium, Halomonas marina HMA 103 isolated from solar saltern of Orissa, India," Acta Microbiologica et Immunologica Hungarica, vol. 56, no. 2, pp. 125-143, 2009.

[10] S. Y. Jayachandra, S. Anil Kumar, D. P. Merley, and M. B. Sulochana, "Isolation and characterization of extreme halophilic bacterium Salinicoccus sp. JAS4 producing extracellular hydrolytic enzymes," Recent Research in Science and Technology, vol. 4, no. 4, pp. 46-49, 2012. 
[11] I. W. Sutherland, "Novel and established applications of microbial polysaccharides," Trends in Biotechnology, vol. 16, no. 1, pp. 41-46, 1998.

[12] M. W. Mittelman and G. G. Geesey, "Copper-binding characteristics of exopolymers from a freshwater-sediment bacterium," Applied and Environmental Microbiology, vol. 49, no. 4, pp. 846851, 1985.

[13] J. Anton, I. Meseguer, and F. Rodriguez-Valera, "Production of an extracellular polysaccharide by Haloferax mediterranei," Applied Enviromental Microbiology, vol. 54, no. 10, pp. 23812386, 1988.

[14] H. Parolis, L. A. S. Parolis, I. F. Boán et al., "The structure of the exopolysaccharide produced by the halophilic Archaeon Haloferax mediterranei strain R4 (ATCC 33500)," Carbohydrate Research, vol. 295, pp. 147-156, 1996.

[15] E. Quesada, V. Bejar, and C. Calvo, "Exopolysaccharide production by Volcaniella eurihalina," Experientia, vol. 49, no. 12, pp. 1037-1041, 1993.

[16] J. A. Mata, V. Béjar, I. Llamas et al., "Exopolysaccharides produced by the recently described halophilic bacteria Halomonas ventosae and Halomonas anticariensis," Research in Microbiology, vol. 157, no. 9, pp. 827-835, 2006.

[17] I. Llamas, J. A. Mata, R. Tallon et al., "Characterization of the exopolysaccharide produced by Salipiger mucosus $A 3^{T}$, a halophilic species belonging to the Alphaproteobacteria, isolated on the Spanish Mediterranean seaboard," Marine Drugs, vol. 8, no. 8, pp. 2240-2251, 2010.

[18] F. Martínez-Checa, E. Quesada, J. Martínez-Cánovas, I. Llamas, and V. Béjar, "Palleronia marisminoris gen. nov., sp. nov., a moderately halophilic, exopolysaccharide-producing bacterium belonging to the 'Alphaproteobacteria', isolated from a saline soil," International Journal of Systematic and Evolutionary Microbiology, vol. 55, no. 6, pp. 2525-2530, 2005.

[19] A. Ventosa, M. T. Garcia, M. Kamekura, H. Onishi, and F. Ruiz-Berraquero, "Bacillus halophilus sp. nov., a moderately halophilic Bacillus species," Systematic and Applied Microbiology, vol. 12, no. 2, pp. 162-166, 1989.

[20] R. A. Moraine and P. Rogovin, "Kinetics of polysaccharide B 1459 fermentation," Biotechnology and Bioengineering, vol. 8, no. 4, pp. 511-524, 1966.

[21] M. Dubois, K. A. Gilles, J. K. Hamilton, P. A. Rebers, and F. Smith, "Colorimetric method for determination of sugars and related substances," Analytical Chemistry, vol. 28, no. 3, pp. 350356, 1956.

[22] O. H. Lowry, N. J. Rosenbrough, A. L. Farr, and R. J. Randall, "Protein measurement with the Folin phenol reagent.," The Journal of Biological Chemistry, vol. 193, no. 1, pp. 265-275, 1951.

[23] P. Gerhardt, R. G. E. Murray, W. A. Wood, and N. R. Krieg, Methods for General and Molecular Bacteriology, American Society for Microbiology, Washington, DC, USA, 1994.

[24] G. M. Garrity, J. A. Bell, and T. G. Lilburn, “Taxonomic outline of the procaryotes," in Bergey's Manual of Systematic Bacteriolog, D. R. Boone and R. W. Castenholz, Eds., Springer, New York, NY, USA, 2nd edition, 2003.

[25] J. A. Mata, J. Martínez-Cánovas, E. Quesada, and V. Béjar, "A detailed phenotypic characterisation of the type strains of Halomonas species," Systematic and Applied Microbiology, vol. 25, no. 3, pp. 360-375, 2002.

[26] A. Oren, "Molecular ecology of extremely halophilic archaea and bacteria," FEMS Microbiology Ecology, vol. 39, no. 1, pp. 1-7, 2002.
[27] H. Baati, R. Amdouni, N. Gharsallah, A. Sghir, and E. Ammar, "Isolation and characterization of moderately halophilic bacteria from tunisian solar saltern," Current Microbiology, vol. 60, no. 3, pp. 157-161, 2010.

[28] A. Hedi, N. Sadfi, M. Fardeau et al., "Studies on the biodiversity of halophilic microorganisms isolated from El-Djerid salt lake (Tunisia) under aerobic conditions," International Journal of Microbiology, vol. 2009, Article ID 731786, 17 pages, 2009.

[29] M. Birbir, A. Ogan, B. Calli, and B. Mertoglu, "Enzyme characteristics of extremely halophilic archaeal community in Tuzkoy Salt Mine, Turkey," World Journal of Microbiology and Biotechnology, vol. 20, no. 6, pp. 613-621, 2004.

[30] M. Birbir and C. Sesal, "Extremely halophilic bacterial communities in Sereflikochisar Salt Lake in Turkey," Turkish Journal of Biology, vol. 27, no. 7, pp. 7-22, 2003.

[31] M. Birbir, B. Calli, B. Mertoglu et al., "Extremely halophilic Archaea from Tuz Lake, Turkey, and the adjacent Kaldirim and Kayacik salterns," World Journal of Microbiology and Biotechnology, vol. 23, no. 3, pp. 309-316, 2007.

[32] R. Rohban, M. A. Amoozegar, and A. Ventosa, "Screening and isolation of halophilic bacteria producing extracellular hydrolyses from Howz Soltan Lake, Iran," Journal of Industrial Microbiology and Biotechnology, vol. 36, no. 3, pp. 333-340, 2009.

[33] M. J. Garabito, M. C. Márquez, and A. Ventosa, "Halotolerant Bacillus diversity in hypersaline environments," Canadian Journal of Microbiology, vol. 44, no. 2, pp. 95-102, 1998.

[34] A. Ventosa, A. Ramos-Cormenzana, and M. Kocur, "Moderately halophilic gram-positive cocci from hypersaline environments," Systematic and Applied Microbiology, vol. 4, no. 4, pp. 564-570, 1983.

[35] E. Quesada, A. Ventosa, F. Rodriguez-Valera, and A. R. Cormenzana, "Types and properties of some bacteria isolated from hypersaline soils," Journal of Applied Bacteriology, vol. 53, no. 2, pp. 155-161, 1982.

[36] E. Quesada, V. Bejar, M. J. Valderrama, A. Ventosa, and A. R. Ramos Cormenzana, "Isolation and characterization of moderately halophilic nonmotile rods from different saline habitats.", Microbiologia, vol. 1, no. 1-2, pp. 89-96, 1985.

[37] S. R. Dave and H. B. Desai, "Microbial diversity at marine salterns near Bhavnagar, Gujarat, India," Current Science, vol. 60, no. 4, pp. 497-500, 2006.

[38] S. Kumar, R. Karan, S. Kapoor, S. P. Singh, and S. K. Khare, "Screening and isolation of halophilic bacteria producing industrially important enzymes," Brazilian Journal of Microbiology, vol. 43, no. 4, pp. 1595-1603, 2012.

[39] B. P. Dave and A. Soni, "Diversity of halophilic archaea at salt pans around Bhavnagar coast, Gujarat," Proceedings of the National Academy of Sciences India Section B: Biological Sciences, vol. 83, no. 2, pp. 225-232, 2013.

[40] A. A. Joshi, P. P. Kanekar, A. S. Kelkar et al., "Cultivable bacterial diversity of alkaline Lonar lake, India," Microbial Ecology, vol. 55, no. 2, pp. 163-172, 2008.

[41] T. M. Raghavan and I. Furtado, "Occurrence of extremely halophilic Archaea in sediments from the continental shelf of west coast of India," Current Science, vol. 86, no. 8, pp. 10651067, 2004.

[42] S. Vijayanand, J. Hemapriya, J. Selvin, and S. Kiran, "Biodiversity of extremely halophilic bacterial strains isolated from solar salterns of Tuticorin, Tamilnadu, India," International Journal of Water Resources and Environmental Sciences, vol. 1, no. 1, pp. 1-7, 2012. 
[43] S. G. Nanjani and H. P. Soni, "Isolation and characterization of extremely halotolerant and halophilic organisms from Dwarka and Veraval," Journal of Pharmacy and Biological Sciences, vol. 2, no. 2, pp. 20-25, 2012.

[44] H. Ghozlan, H. Deif, R. A. Kandil, and S. Sabry, "Biodiversity of moderately halophilic bacteria in hypersaline habitats in Egypt," Journal of General and Applied Microbiology, vol. 52, no. 2, pp. 63-72, 2006.

[45] D. R. Arahal, M. T. García, W. Ludwig, K. H. Schleifer, and A. Ventosa, "Transfer of Halomonas canadensis and Halomonas israelensis to the genus Chromohalobacter as Chromohalobacter canadensis comb. nov. and Chromohalobacter israelensis comb. nov," International Journal of Systematic and Evolutionary Microbiology, vol. 51, no. 4, pp. 1443-1448, 2001. 

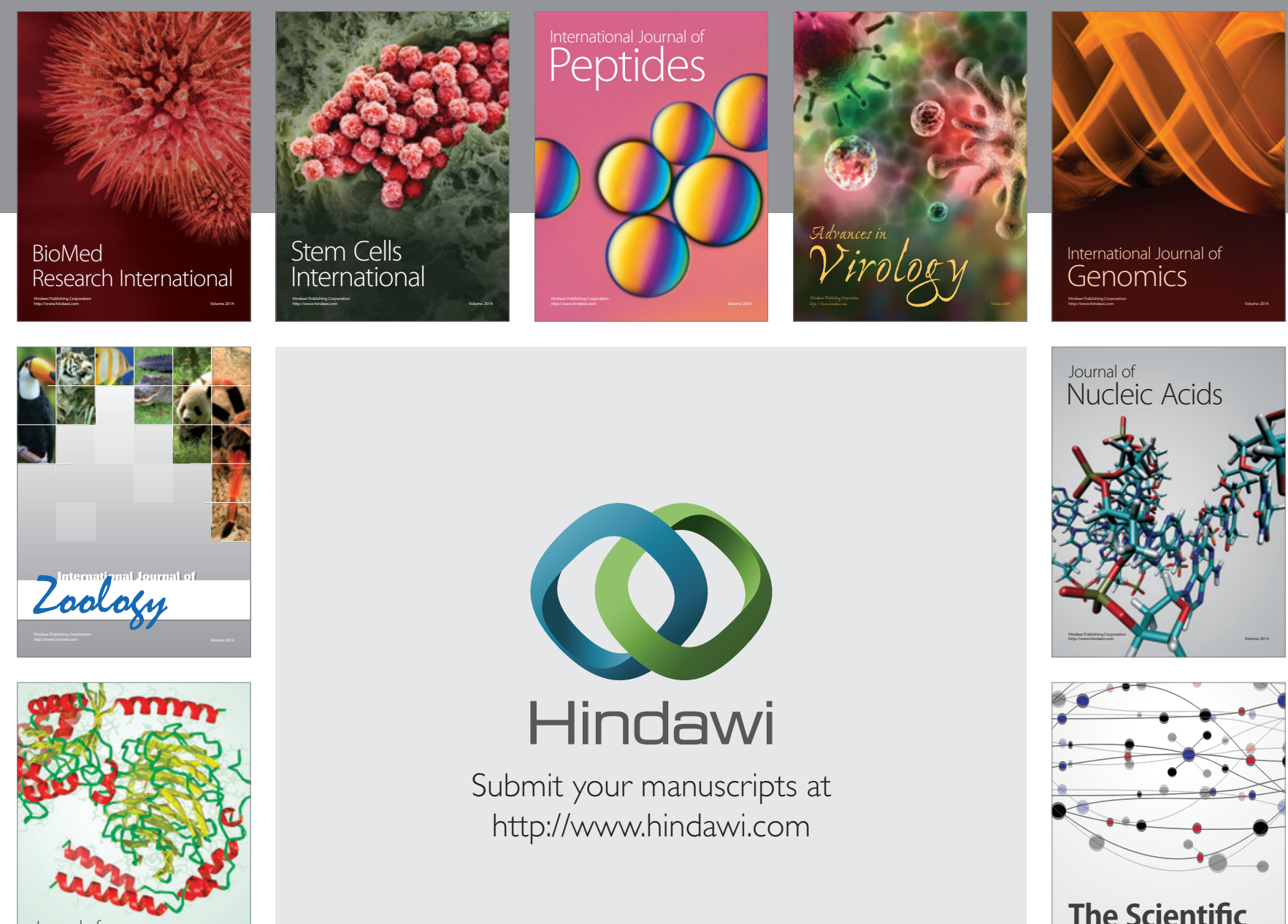

Submit your manuscripts at

http://www.hindawi.com

Journal of
Signal Transduction
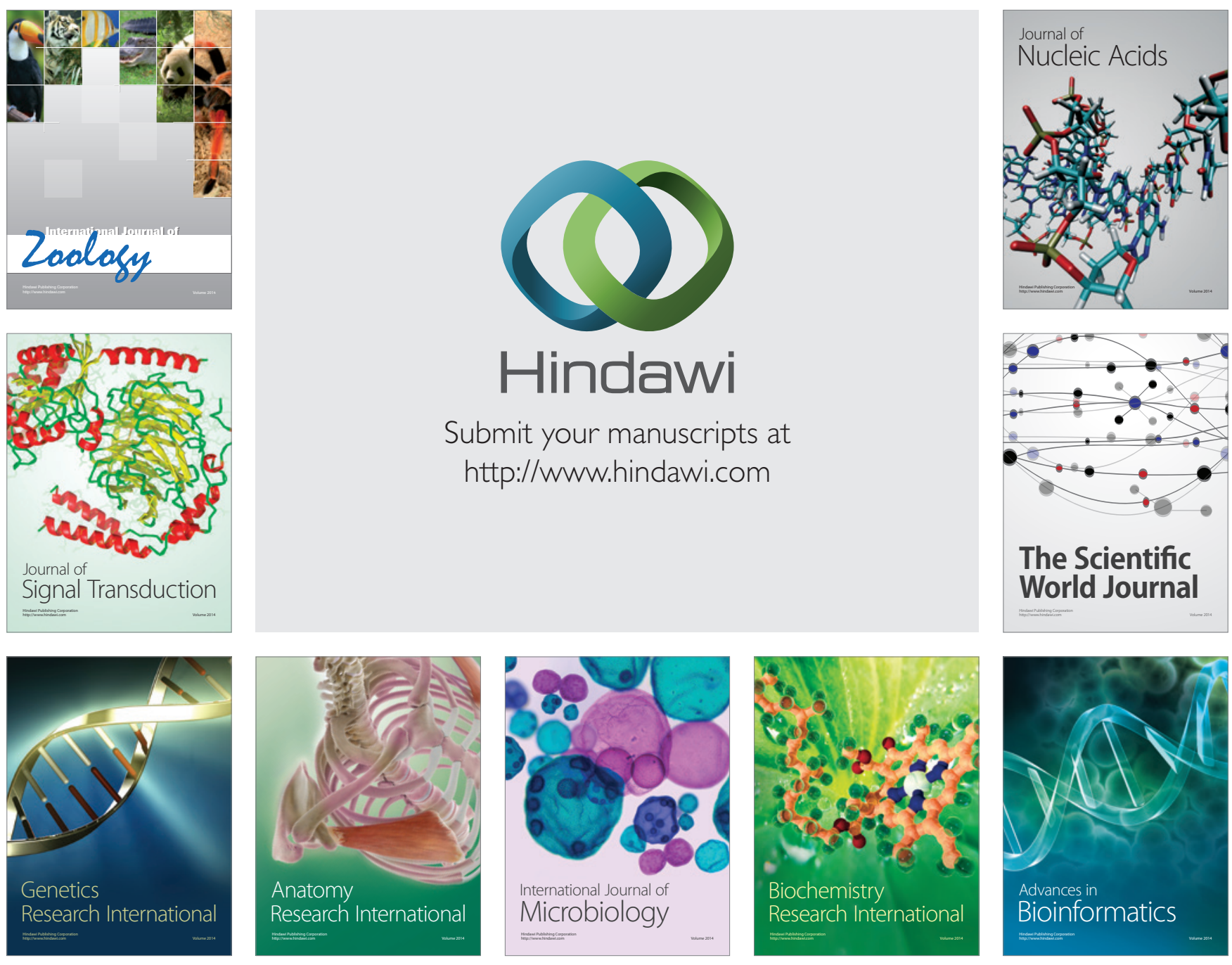

The Scientific World Journal
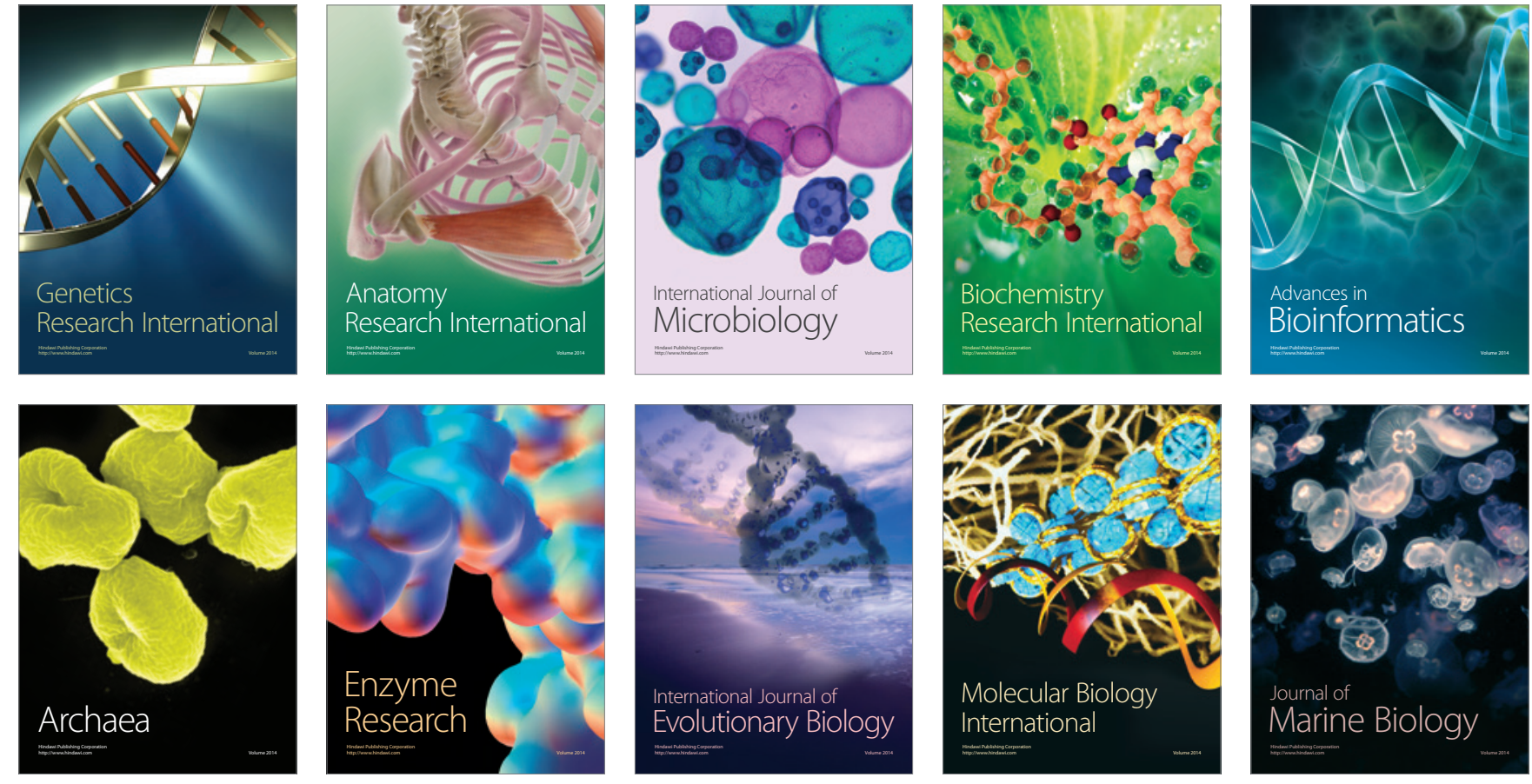